\title{
Matematikai módszerek a mechanikában
}

\author{
Andor Krisztián, Polgár Rudolf \\ NymE SKK, Müszaki Mechanika és Tartószerkezetek Intézet \\ krisztian.andor@skk.nyme.hu, polgar@nyme.hu
}

\begin{abstract}
ÖSSZEFOGLALÓ. A kényszerpályás közlekedés esetén a mozgás alapján meghatározott pálya alapvető követelmény. A lineáris görbületi tulajdonságú klotoid átmenetiívet spline-okkal modellezve eddig ismeretlen információkhoz jutottunk. A modellezés további dimenziókat is feltárt, mely során egyszerüen vizsgálhatókká váltak egyéb mozgáskinematikai effektusok.

ABSTRACT. In railway transportation it is a fundamental requirement to have track geometry that corresponds to the desired motion. With the modelling of the clothoide transition curve with splines, hitherto unknown information are gained. This modelling has open new dimensions, which helps the simply examination of other kinematic motion-effects.
\end{abstract}

\section{A mozgás leírása}

A kötöttpályás vasúti közlekedésnél a pályának meghatározó szerepe van a jármü mozgása során ébredő kinematikai igénybevételek keletkezésében. Ezért fontos, hogy olyan geometriai kialakításúak legyenek az íves vágányszakaszok, melyen a kinematikai mozgásjellemzők értékei küszöbérték alatt maradnak. A tervezés során ezért kinematikai szempontok nem hagyhatók figyelmen kívül.

A különböző görbületi tulajdonságú pályaszakaszok (körív = konstans görbület, egyenes $=0$ görbület) a hirtelen változó oldalgyorsulás miatt nem követhetik egymást, ezért közéjük iktatják be az átmenetiívet, mely a két eltérő, konstans görbületű szakaszt egy változó görbületü szakasszal köti össze, biztosítva ezzel az oldalgyorsulás fokozatos növekedését vagy csökkenését, szemben az ugrásszerü változással. A vasútépítésben az oldalgyorsulás megváltozását $\overline{\mathbf{h}}$-vektornak nevezik, mely magasabbrendủ kinematikai mozgásjellemzőnek számít, és azt döntően a görbületfüggvény ívhossz szerinti első deriváltja befolyásolja. A $\overline{\mathbf{h}}$-vektor - éppúgy, mint az oldalgyorsulás - nem léphet át egy határértéket, mely a pálya és az utasok fokozottabb igénybevételét okozná.

A hullámos görbületfüggvényü átmenetek esetén a függvény deriváltja minden nehézség nélkül előállítható, azonban a lineáris görbületfüggvény töréspontjaiban a derivált értelmezhetetlen. Noha kinematikai szempontból a lineáris görbületfüggvényt szakaszosan deriválva a legjobb geometriai kialakítású átmenetiív lenne, a két csatlakozási pontban (görbületi töréspontokban) a kinematikai mozgásjellemzök nem ismertek, így feltételezhető akár, hogy elméletileg végtelen nagy értékeket vehetnek fel. Erre alapozva külön csoportokra bontották az átmenetiíveket a görbületfüggvényük deriválhatósága szerint. Így más határértékek vonatkoztak a folytonosan differenciálható görbületfüggvényü, és más, szigorúbb határértékek a töréses görbületfüggvényü átmenetiívekre.

Értekezésemben kettéosztás szükségtelen voltára hívom fel a figyelmet.

Mivel a klotoid átmenetiív a legelterjedtebb átmenetiív-fajta a világon, joggal felmerül az igény az átmenetiívvel kapcsolatos általános ismeretek kiegészítésére. 


\section{A spline-okkal modellezett vasúti vágánytengely-vonal leírása}

A klotoid átmenetiív csatlakozásainál fellépő $\overline{\boldsymbol{h}}$-vektor nagyságának numerikus meghatározására van szükség, hogy közvetlenül összehasonlítható legyen más, folytonosan deriválható görbületfüggvényü, átmenetiívekkel.

Erre biztosított lehetőséget a spline-elmélet. A spline-okkal leírható módszert müszaki területen alkalmazták már a középkorban is. A hajóépítésben felvetődött probléma - miszerint az áramvonalas hajótest-geometriát egy meggörbített pálca vonala szolgáltja - és a vasúti átmenetiívek kialakítása között analógia található. Matematikailag ezt a modellt a splineokkal lehet leírni.

A spline-okkal leírt a vasúti pálya modelljének több szempontnak kell megfelelnie.

Az első szempont alapján, a pályagörbe modelljétől elvárjuk, hogy legalább négyszer folytonosan differenciálható legyen, még az átmenetiív eleje és vége pontban is. A spline-ok rendüségét mi választhatjuk meg, így a kellő számú differenciálás végrehajtható. Így az eredetileg töréses görbületfüggvényü pálya spline-nal közelített modelljének görbületfüggvénye nem töréses lesz. A kérdéses pontokban folytonosan differenciálható függvényeket vizsgálhatunk. Amennyiben legalább ötödfokú spline-nal dolgozunk, a görbületfüggvény első és második deriváltfüggvénye előállítható lesz.

A második szempont szerint a kitüzési pontok nem esnek az ideális pálya vonalába, melynek okai a következők:

- A kitüzési koordináták nem egzakt módon, hanem a sorbafejtés során, csupán a hatványsor első két tagjának figyelembevételével lettek kiszámítva.

- Az így kiszámított értékeket az ívkitüző zsebkönyv csak mm-re kerekített pontossággal adja meg.

- A geodéziai kitűzés során a kitűzési koordináták kitűzési hibával terheltek.

Ez azt eredményezi, hogy a fent említett módon meghatározott koordinátapontok (kitüzési pontok) hol az ideális pálya egyik, hol a másik oldalára kerülnek és minimális annak az esélye, hogy tökéletesen a göbe vonalára essenek.

$\mathrm{Az}$ alapgondolat szerint a spline-nal lehetséges olyan függvényt konstruálni, mely nem illeszkedik közvetlenül a kitüzési pontokra, és a kitüzési pontossággal elkövetett hibát nem haladja meg.

Az approximációs spline értéke egy adott illeszkedési pontnál (64) szerint:

$$
\tilde{y}_{i}=y_{i} \pm \varepsilon_{i},
$$

ahol: $\quad \tilde{y}_{i}$ a spline értéke,

$y_{i} \quad$ a kitüzési pont $y$ ordináta értéke,

$\varepsilon_{i} \quad$ a spline értéke és a pont közötti eltérés.

$\mathrm{Az} \varepsilon_{i}$ eltéréseknek kicsiny értéküeknek kell lenniük, ami esetünkben teljesül, hiszen a koordináták meghatározásakor a sorbafejtés és a kerekítés során csupán tizedmilliméteres hibákat vétünk. Az így előállított görbéről elmondható, hogy nem túl nagy eltérésekkel illeszkedik a kitűzési pontokra, miközben igyekszik egy minimális összgörbület-változású görbe vonalát adni.

Miután számunkra a tervek és az ívkitűző zsebkönyv adatai alapján kitüzött pályán ébredő kinematikai igénybevételek nagysága a meghatározó, (nem pedig az elméleti függvényen keletkező mozgásjellemzőké) a vágánytengely spline-nal történő helyettesítésével a valósághoz közelebb álló eredményt kapunk, amennyiben a hiba határértéke a megvalósíthatósági pontosságot nem haladja meg.

A harmadik, a modellezésnél figyelembeveendő szempont szerint a pontok eltérő nagyságban térnek el az ideális görbe vonalától, ezért figyelembe kell venni az eltérések nagyságának változását. Az eltéréseket úgy célszerủ súlyozni, hogy a spline nagyobb súllyal 
közelítse a minimális összgörbület-változású görbe vonalához közel eső pontokat, és kisebb súllyal a távolabb esőket.

A görbületfüggvény - amely alapján a kitüzési koordináták adottak - csupán a kitüzési pontokban és a görbületfüggvényböl történő inetrpolálással az aljaknál egyezik a kivitelezett pálya görbületfüggvényével, míg a pontok között azt a sínpár rugalmassága határozza meg.

\section{A spline-ok alkalmazásával létrehozott átmenetiív geometriai pontossága}

A spline-elmélettel kapott görbe illeszkedési pontosságát bemutatandó, meghatároztam a kitüzési értékpárokat 1,0 m-es egymást követő távolságra századmilliméteres pontossággal. Ezt tekintem elméleti kitüzésnek

Az 5 m-es távolságra lévő kitüzési pontokra illesztett spline-helyszínrajz-függvényről leolvasott méterenkénti értékek és az elméleti kitűzés közötti $\Delta f(x, y)=f(x, y)_{\text {kitüzési }}-f(x, y)_{\text {méterenkent }}$ eltérés szintén elhanyagolható volt. A legnagyobb eltérés nagysága nem haladta meg a fél millimétert.

Tekintettel arra, hogy a megépítés során a kitüzési koordináták mm-re kerekítve adottak, és ezen pontok a kitüzési hibával terhelten lesznek kitüzve, a spline-elmélettel meghatározott átmenetiívmodell pontossága meghaladja az elvárásokat. Ezzel igazolható, hogy a splineelmélet segítségével lehetséges a gyakorlatban az átmenetiívek megfelelő pontosságú modelljeinek létrehozása.

\section{A kinematikai mozgásjellemzők meghatározása az átmenetiívek mentén}

A fenti szempontokat kielégítő modellezéssel kiszámíthatók lettek a klotoid átmenetiív esetében a magasabbrendü kinematikai mozgásjellemző vektorok a két, eddig kérdéses csatlakozási pontokban is.

Ezeket az értékeket közvetlenül össze lehet hasonlítani más típusú átmenetiíveknél kapott igénybevétel-értékekkel.

A görbületváltozás jellege alapján megkülönböztetett, elméleti feltételezéseken alapuló elöírások nem befolyásolják az átmenetiívek összehasonlíthatóságát.

Az elméleti megfontolások alapján a görbület által meghatározott pályavonal a gyakorlatban csupán pontokban egyezhet a megvalósítandó pálya vonalával, mivel a gyakorlatban a vágánytengely vonalát a kitüzési pontok határozzák meg. Az elméleti görbületfüggvény közelítésével csak milliméter pontossággal lehet kitüzni 3-5 méteres távolságban a pontokat, melyekre fektetik a vasúti vágányt. Az aljtávolságra besürített illeszkedési pontok között a vágány alakját a sín görbülése határozza meg. Megállapítható, hogy a pályatengelyt meghatározó elmélet, és a megvalósult pályatengely között differencia van. Ezt az eltérést érdemes figyelembe venni a vasúti vágány modellezése során.

Az elméleti pályatengely és a megvalósult pályatengely közötti eltérést tudjuk a splineokkal figyelembe venni, mivel azok természetükből fakadóan viselkednek úgy, ahogyan a gyakorlatban a meghajlított vasúti sín. A spline-ok további tulajdonságai közé tartozik a rendjük meghatározhatósága, így a pályagörbe vonalát leíró függvény szükséges mennyiségben folytonosan deriválható (nem csak szakaszonként), ezek után a magasabbrendủ kinematikai mozgásjellemző vektorok függvényei is meghatározhatók.

A spline-okkal modellezett klotoid átmenetiíven - a spline megfelelő mennyiségben és folytonos deriválhatósága miatt - a keletkező kinematikai mozgásjellemző vektorok 
függvényei pontosan meghatározhatókká váltak. A spline-elmélet segítségével kapott kinematikai igénybevétel-szélsőértékek a klotoid átmenetiív esetében közvetlenül összehasonlíthatókká váltak más átmenetiíveknél számított szélsőértékekkel. Az összehasonlítások elvégeztével - a megépíthetőségi pontosságot is figyelembe véve - a klotoid átmenetiív bizonyult minden esetben kinematikai szempontból a legjobb átmenetiívgeometria kialakításnak.

\section{Súlypontpálya leírása}

Vizsgálat tárgyává tettem a vágány tengelyvonala, és a merev testszerü kocsiszekrény súlypontpályája közötti eltérés meghatározását.

A kutatást a kinematikai vizsgálatok során a mozgás pontmozgásként történő modellezése indokolta. A kocsiszekrény súlyát - pontként való helyettesítése során - a súlypontba célszerü sűríteni. A súlypont pályáján ébredő kinematikai igénybevételek a meghatározók, és nem a vágánytengely-pályán keletkezők, ahol csupán a megvezetett kocsiszekrény forgózsámolyai futnak. Ezáltal a klotoid átmenetiív csatlakozásainál lévő görbületi törés lekerekedik, ami kedvezően befolyásolja a magasabbrendü kinematikai mozgásjellemzők alakulását. Ez ismét a klotoid átmenetiív alkalmazásának előnyét bizonyítja kinematikai szempontból.

\section{Irányhibák lokalizálása és meghatározása a spline-módszerrel}

A spline-elmélet - természetéből fakadóan - irányhiba lokalizálására is alkalmas. Irányhibák lokalizálására történő alkalmazhatóságát más szabályozómódszerrel (érintőszögeljárás) történt összehasonlítással vizsgáltam. Az approximációs súlyozással közelítő spline figyeli a minimális összgörbület-változású görbétől a pontok távolságát, és ezen távolság alapján veszi figyelembe a pont súlyát a görbe megalkotásában. Ez a súlyozás állítható be úgy, hogy a spline a megvalósíthatósági pontosságot figyelembe véve illeszkedjen a kitüzési pontokra. Így a túlzott eltérések olyan következményekkel járnak, hogy a splineelmélet alulsúlyozza az adott hibás pontot, és a spline görbéjének meghatározásában nem játszik szerepet. Vagyis az így kieső pontok kigyüjthetők, a görbétől való távolságuk meghatározható, mely egyben a szabályozás értéke is.

\section{Irodalomjegyzék}

[1] Vaszary P.: Vasútépítés és Pályafenntartás I., MÁV Rt., Budapest, (1999) 35-56.

[2] Megyeri J.: Vasúti mozgásgeometria, Müszaki Könyvkiadó, Budapest, (1986).

[3] Hasslinger, L. H., Stockinger, H.: Messtechnischer Nachweis der Überlegenheit eines neuen Trassierungselement, des „Wiener Bogens”, ZEVrail Glasers Annalen, 128. évf. (2004) szept., 66-77.

[4] Hainitz, H., Heindl, W. , Presle G.: Neugestaltung von Übergangsbögen. Öster-reichische Ingenieur- und Architekten-Zeitschrift, 138. évf. 10. sz., (1993) 388-395.

[5] Kisgyörgy L.: Szinuszhiperbolikusz átmenetiív, Tudományos Diákköri Konferencia dolgozat, Budapesti Müszaki Egyetem, Vasútépítési Tanszék, Budapest, (1994).

[6] Sard, A., Weintraub, S.: A book of splines, John Wiley and Sons, Mc. New York, (1971).

[7] Polgár R.: Általánosított spline-approximáció, Geomatikai közlemények VII. MTA GGKI, Sopron, (2004) 197-209.

[8] Kerkápoly E.. Megyeri J.: Vasúti ívkitüzési táblázatok, Müszaki Könyvkiadó, Budapest, (1980).

[9] Megyeri J.: Vasútépítéstan, Közlekedési Dokumentációs Vállalat, Budapest, (1991).

[10] Kormos Gy.: Ívszabályozás számításos érintőszög-eljárással koszinusz-átmenetiív esetén. Közlekedéstudományi Szemle, 45. évf. 1. sz., (1995) 18-23.

[11] Andor K., Polgár R.: Localization of bearing errors using spline method, Periodica Polytechnica $\boldsymbol{C E}$ 58:(7528), (2014) 1-7, (doi: http://dx.doi.org/10.3311/PPci.7528). 